\title{
ANTI-BACTERIAL ACTIVITIES OF SOME ACTIVE CONSTITUENTS ISOLATED FROM PHLOMIS FLOCCOSA D. DON.
}

\author{
Rehab A. Lotfy and Heba I. Abd El-Moaty ${ }^{*}$ \\ Department of Medicinal and Aromatic Plants, Desert Research \\ Center El-Matareya, Cairo, Egypt \\ *E-mail: torkeyheba@yahoo.com
}

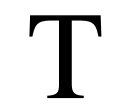

he present study aimed to evaluate the anti-bacterial activities (in vitro) of the total extract of $70 \%$ methanol and successive extracts of different organic solvents (petroleum ether, chloroform, methanol, 50\% methanol extracts), and their isolated compounds of the vegetative parts and flowers of Phlomis floccosa against Escherichia coli, Klebsiella pneumonia, Proteus spp. and Staphylococcus aureus. Where the best antibacterial active extract for vegetative parts was chloroform, while it was petroleum ether extract for flowers. Isolation and purification of the major compounds of the active fractions concluded that, 7, 3', 4'-trimethoxy quercetin (flavonoid) and hahnfett (hydrocarbon) were detected in the vegetative parts, meanwhile, stewertiisin B (sesquiterpene) was detected in the flowers. The three isolated compounds showed active inhibition of the bacterial growth.

Keywords: Phlomis floccosa, flavonoid, hydrocarbons, sesquiterpene, antibacterial activities

Plant extracts constitute a natural source of antimicrobial mixtures or pure compounds for centuries. The purified components are used as natural antimicrobials in food systems, as well as to prevent the growth of foodborne bacteria and molds, resulting in extension of the shelf life of processed foods (Kalemba and Kunicka, 2003 and Burt, 2004). Phlomis species are explained by dioscorides as herbal medicines, and are in practice ethnopharmacological in herbal drugs for respiratory tract ailments and for local healing of injuries (Bucar et al., 1998). Some Phlomis species are used in folk medicine for their analgesic and antidiarrheal properties, and for the treatment of ulcers and hemorrhoids (Kirmizibekmez et al., 2005). There are few reports about the pharmacological and biological effects of Phlomis, some studies have shown various activities, such as anti-inflammatory, immunosuppressive, antimutagenic, anti-nociceptive, antifibriel, free radical scavenging, anti-malarial, and anti-microbial effects (Sarkhail et al., 2006). 
Different classes of glycosides comprising diterpenoids, iridoids, phenylpropanoids, phenylethanoids and flavonoids have been identified from the genus Phlomis. Many of these phenylpropanoids showed significant biological activities, such as cytotoxic, cytostatic, antiinflammatory, immuno-suppressant and antimicrobial (Kamel et al., 2000 and Ben Amor et al., 2009), while Jabeen et al. (2013) isolated four new compounds (stewartiiside, stewartiisin A, stewartiisin B and stewartiisin C) and nine known compounds from Phlomis stewartii. The leaves of Phlomis aurea contained the 7-glucosides, 7-rutinosides and 7-pcoumaroylglucosides of naringenin, apigenin, luteolin and chrysoeriol, hispidulin 7-glucoside, luteolin 7-diglucoside, vicenin-2 and lucenin-2. The microscopic hairs on the leaves only contained the 7-monoglucosides and their acylated derivatives. Phlomis floccosa showed a similar flavonoid pattern, but with no flavanones (El-Negoumy et al., 1986).

\section{MATERIALS AND METHODS}

\section{Plant Material}

The vegetative parts and flowers of Phlomis floccosa were collected at full flowering stage from Mersa Matruh during April 2011. The plant was identified in the Herbarium of the Desert Research Centre. They were air dried, then ground to fine powder and kept to be used for analyses.

\section{Extraction of Total Extract}

About 80 gram from each of the vegetative parts and the flowers were extracted separately with $70 \%$ methanol. The obtained residue from each part was dried and weighed.

\section{Extraction Using Different Organic Solvents Successive extraction technique}

About 700 gram of the vegetative parts and 250 gram of the flowers were subjected to extraction with successive organic solvents using Soxhlet apparatus, in order to increase polarity, including petroleum ether (b.p. 40-60 ${ }^{\circ} \mathrm{C}$ ), chloroform, methanol and $50 \%$ methanol. The obtained residue from each solvent was dried and weighed.

\section{Antibacterial Activity of Different Extracts}

Under aseptic conditions, the antibacterial activity of total extract, petroleum ether, chloroform, methanol and 50\% methanol extracts (100 $\mu \mathrm{g} / \mathrm{ml}$ ), of the aerial parts and flowers of Phlomis floccosa, as well as the 
three isolated compounds $(25 \mu \mathrm{g} / \mathrm{ml})$ were carried out by the cup diffusion method (Vivek et al., 2010). For preparation of bacterial inocula, the bacterial density was adjusted to approximately $10^{8}$ colony forming units (CFU) per ml (optical density was adjusted to 0.5 McFarland turbidity). Bacterial suspension was spread over the plates containing Mueller-Hinton agar, using a sterile cotton swab, in three directions in order to get a uniform microbial growth (Kateryna and Mahendra, 2012). Three wells of $5 \mathrm{~mm}$ diameter each were made in agar Petri plate of the solidified agar medium using sterilized cork borer. All plates were then incubated at $37^{\circ} \mathrm{C}$ for 24 hours. After incubation, average diameters of inhibition zones around the discs were measured in mm (Bülent et al., 2011 and Hanene et al., 2013).

\section{Tested Bacteria}

Four clinical isolates of bacterial strains, were isolated from ElDemerdash hospital patients. They were identified and used for investigating the antibacterial activity of the plant extracts and isolated compounds, including Escherichia coli, Klebsiella pneumonia, Proteus spp. and Staphylococcous aureus.

\section{Separation and Identification of Active Constituents}

The most antibacterial active fractions of vegetative parts and flowers (chloroform and petroleum ether extracts, respectively) were applied separately on the top of a Sephadex LH- 20 column (A and B, respectively). Elution was started with pure ethanol, followed by a mixture of ethanol/water and finally distilled water was applied. The received fractions were evaporated and subjected to TLC using the solvent system chloroform: methanol (9: $1 \mathrm{v}: \mathrm{v})$ where similar fractions were collected together.

The column (A) from the vegetative parts led to two main fractions (I and II). Fraction (I) contained one spot only represented compound (1). Fraction (II) reapplied to a Sephadex LH- 20 column using methanol as eluent, this led to isolation of compound (2). While, column (B) from the flowers led to isolation of one pure compound (3).

\section{Identification of Isolated Compounds}

The NMR measurements were carried out on Bruker High Performance Digital FT-NMR Spectrometer Advanced III $400 \mathrm{MHz}(270$ $\mathrm{MHz}$ for ${ }^{1} \mathrm{H}-\mathrm{NMR}$ and $67.5 \mathrm{MHz}$ for $\left.{ }^{13} \mathrm{C}-\mathrm{NMR}\right)$. 


\section{RESULTS AND DISCUSSION}

\section{Extraction of Total Extract}

The obtained data showed that, total extracts $(70 \%$ methanol) of vegetative parts and flowers were 23.34 and $14.62 \%$, respectively.

\section{Successive Extraction Using Different Organic Solvents}

Data presented at table (1) showed that, methanol extracts had the highest values (10.11 and 7.51\%) obtained from vegetation parts and flowers, respectively.

Table (1). Successive extraction residues (\%) of vegetative parts and flowers of Phlomis floccosa D. Don.

\begin{tabular}{ccc}
\hline Solvent used & \multicolumn{2}{c}{ Residue percentage (\%) } \\
\cline { 2 - 3 } & Vegetative parts & Flowers \\
\hline Petroleum ether (b.p. $\left.40-60{ }^{\circ} \mathrm{C}\right)$ & 5.94 & 2.40 \\
Chloroform & 2.21 & 1.50 \\
Methanol & 10.11 & 7.51 \\
Methanol 50\% & 5.84 & 4.95 \\
\hline
\end{tabular}

\section{Anti-Bacterial Activity}

Table (2) showed that, the most antibacterial active extracts were chloroform extract of the aerial parts and petroleum ether extract of the flowers. These revealed the isolation of flavonoid and hydrocarbon compounds from chloroform extract and one sesquiterpene from petroleum ether extract. The antibacterial activity of the isolated compounds as shown in fig. (1) indicated that, compounds (1) isolated from the vegetative parts inhibited the bacterial growth of both Escherichia coli and Staphylococci aureus, however it was inactive against the other two bacterial strains. It could also be concluded that, compound (2) posses antibacterial activity against Escherichia coli, Klebsiella pneumonia and Staphylococci aureus. Fig. (2) showed that, compound (3) was active against Escherichia coli and Staphylococci aureus. All the isolated compounds exhibited no antibacterial activity against Proteus spp. This means that, the extractions from which the compounds were isolated are active against Proteus spp. due to the presence of mixture of compounds not to the isolated compounds alone. However, compounds (1, 2 and 3 ) showed better activity after isolation against the other three bacteria as shown in figs. (1 and 2).

Egyptian J. Desert Res., 66, No. 1, 69-78 (2016) 
Table (2). Antibactrial activity of the total extracts, successive extractions and the isolated compounds of Phlomis floccosa D. Don. using disc diffusion assay.

\begin{tabular}{|c|c|c|c|c|c|c|c|c|}
\hline \multirow{3}{*}{ Extracts } & \multicolumn{8}{|c|}{ Inhibation zone (mm)* } \\
\hline & \multicolumn{2}{|c|}{ Escherichia coli } & \multicolumn{2}{|c|}{ Klebsiella pneumonia } & \multicolumn{2}{|c|}{ Proteus spp. } & \multicolumn{2}{|c|}{ Staphylococci aureus } \\
\hline & $\begin{array}{l}\text { Vegetative } \\
\text { parts }\end{array}$ & Flowers & $\begin{array}{l}\text { Vegetative } \\
\text { parts }\end{array}$ & Flowers & $\begin{array}{l}\text { Vegetative } \\
\text { parts }\end{array}$ & Flowers & $\begin{array}{l}\text { Vegetative } \\
\text { parts }\end{array}$ & Flowers \\
\hline Total extract & & & & & & & & \\
\hline $\begin{array}{c}(70 \% \\
\text { methanol) }\end{array}$ & 0 & 0 & 13 & 14 & 16 & 17 & 17 & 14 \\
\hline $\begin{array}{l}\text { Petroleum } \\
\text { ether }\end{array}$ & 16 & 17 & 0 & 18 & 0 & 18 & 0 & 17 \\
\hline Chloroform & 20 & 0 & 19 & 15 & 22 & 14 & 20 & 16 \\
\hline Methanol & 16 & 16 & 21 & 15 & 18 & 17 & 16 & 16 \\
\hline $\begin{array}{c}\text { Methanol } \\
50 \%\end{array}$ & 13 & 12 & 16 & 14 & 20 & 0 & 13 & 13 \\
\hline Compound 1 & 0 & & 23 & & 0 & & 29 & \\
\hline Compound 2 & 24 & & 16 & & 0 & & 24 & \\
\hline Compound 3 & & 0 & & 21 & & 0 & & 18 \\
\hline
\end{tabular}

*Values are the means of three replications

\section{Escherichia coli \\ E Klebsiella pneumonia \\ II Proteus spp. \\ "Stophylococciaureus}

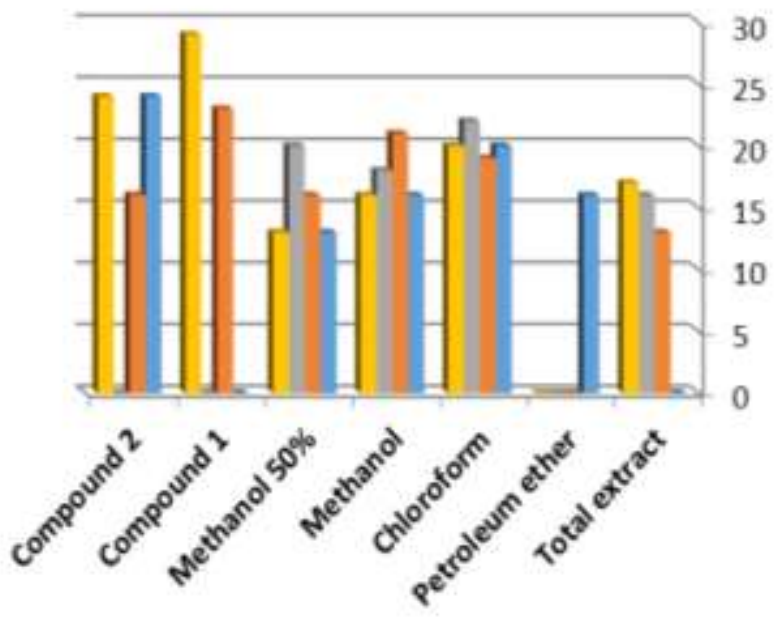

Fig. (1). Antibacterial activity of the total extract, successive extractions and the isolated compounds of Phlomis floccosa D. Don. vegetative parts. 


\section{Escherichia coli \\ - Klebsiella pneumonia \\ Proteus spp. \\ - Staphylococciaureus}

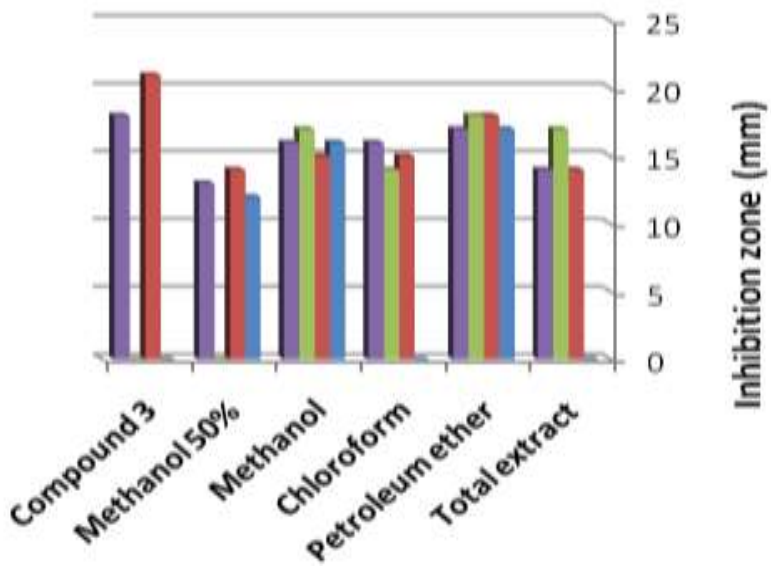

Fig. (2). Antibactrial activity of the total extract, successive extractions and the isolated compounds of Phlomis floccosa D. Don. flowers.

\section{Identification of Active Constituents}

\subsection{Chloroform extract of vegetative parts}

Two compounds were isolated from the chloroform extract of the vegetative parts. Compound (1) identified as 7, 3', 4' trimethoxy quercetin using ${ }^{1} \mathrm{H}-\mathrm{NMR}$ as follows:

${ }^{1} \mathrm{HNMR} \delta: 3.90\left(\mathrm{~s}, 9 \mathrm{H}, \mathrm{OCH}_{3}\right), 6.73\left(\mathrm{~d}, 1 \mathrm{H}, \mathrm{J}=2.44, \mathrm{C}_{6}-\mathrm{H}\right), 6.87(\mathrm{~d}, 1 \mathrm{H}$, $\left.\mathrm{J}=8.24, \mathrm{C}_{8}-\mathrm{H}\right), 6.95\left(\mathrm{~d}, 1 \mathrm{H}, \mathrm{J}=8.36, \mathrm{C}_{6}^{\prime}-\mathrm{H}\right), 7.80\left(\mathrm{~d}, 1 \mathrm{H}, \mathrm{J}=8.4, \mathrm{C}_{5}^{\prime}-\mathrm{H}\right), 7.91$ $\left(\mathrm{d}, 1 \mathrm{H}, \mathrm{J}=4.84, \mathrm{C}_{2}^{\prime}-\mathrm{H}\right)$.

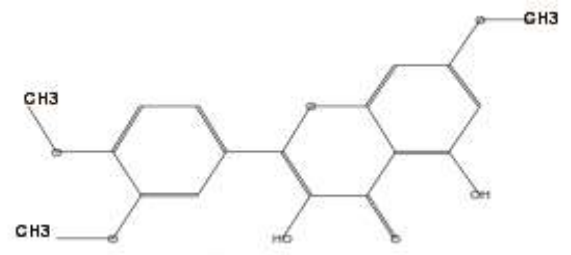

The purified compound (2) was identified as hahnfett using NMR as follows: ${ }^{1} \mathrm{H}-\mathrm{NMR} \delta: 0.80\left(\mathrm{~m}, 6 \mathrm{H}, \mathrm{C}_{1,6}-\mathrm{H}\right), 1.18\left(\mathrm{~m}, 3 \mathrm{H}, \mathrm{C}_{4}-\mathrm{H}\right), 1.54\left(\mathrm{~m}, 4 \mathrm{H}, \mathrm{C}_{2,5}-\mathrm{H}\right)$, $2.24\left(\mathrm{~m}, 1 \mathrm{H}, \mathrm{C}_{3}-\mathrm{H}\right)$.

${ }^{13} \mathrm{C}-\mathrm{NMR} \delta: 14.12,22.69,29.70,31.93$.

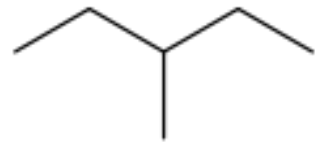

Egyptian J. Desert Res., 66, No. 1, 69-78 (2016) 


\subsection{Petroleum ether extract of the flowers}

The purified compound (3) was identified as stewertiisin B [(17R)19 (18-17)- abeo-2 $\alpha, 16 \beta, 18 \beta, 23,24-p e n t a h y d r o x y-28$-norolean-12-ene-3one] using NMR.

${ }^{1} \mathrm{HNMR} \delta: 0.78\left(\mathrm{~s}, 3 \mathrm{H}, \mathrm{C}_{26}-\mathrm{H}\right), 0.80\left(\mathrm{~m}, 2 \mathrm{H}, \mathrm{C}_{7}-\mathrm{H}\right), 0.81\left(\mathrm{~s}, 3 \mathrm{H}, \mathrm{C}_{30^{-}}\right.$ $\mathrm{H}), 1.06\left(\mathrm{~s}, 3 \mathrm{H}, \mathrm{C}_{29}-\mathrm{H}\right), 1.07\left(\mathrm{~s}, 3 \mathrm{H}, \mathrm{C}_{25}-\mathrm{H}\right), 1.09\left(\mathrm{~m}, 2 \mathrm{H}, \mathrm{C}_{19}-\mathrm{H}\right), 1.19(\mathrm{~m}$, $\left.2 \mathrm{H}, \mathrm{C}_{6}-\mathrm{H}\right), 1.22\left(\mathrm{~s}, 3 \mathrm{H}, \mathrm{C}_{27}-\mathrm{H}\right), 1.37\left(\mathrm{~m}, 1 \mathrm{H}, \mathrm{C}_{1}-\mathrm{H}\right), 1.51-2.23(\mathrm{~m}, 11 \mathrm{H}$,

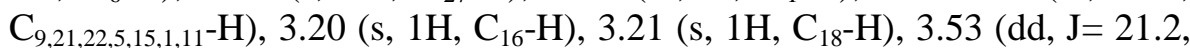
$\left.7.08,1 \mathrm{H}, \mathrm{C}_{2}-\mathrm{H}\right), 4.05\left(\mathrm{~s}, 2 \mathrm{H}, \mathrm{C}_{23}-\mathrm{H}\right), 4.24\left(\mathrm{~s}, 2 \mathrm{H}, \mathrm{C}_{24^{-}} \mathrm{H}\right), 5.25\left(\mathrm{~s}, 1 \mathrm{H}, \mathrm{C}_{12^{-}}\right.$ $\mathrm{H})$.

${ }^{13} \mathrm{CNMR} \delta$ : $13.11,16.98,22.36,22.63,24.62,25.54,26.76,28.80$, $29.06,29.23,29.36,30.22,31.69,33.52,33.69,38.76,46.99,47.42,47.63$, $48.05,48.27,56.95,61.95,63.00,69.26,125.61,129.41,129.55,173.44$.

This compound was isolated as new compound from Phlomis stewartii (Jabeen et al., 2013).

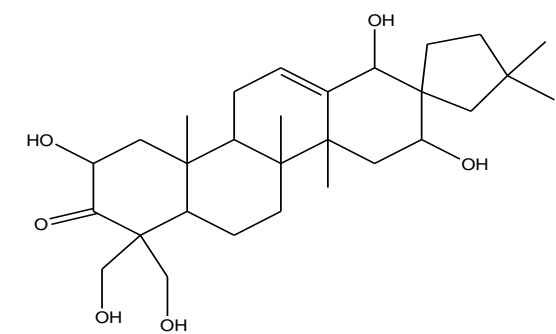

\section{CONCLUSION}

It is the first time to study the antibacterial activity of Phlomis floccosa D. Don. vegetative parts and flowers. All the tested bacterial strains were clinical isolates. It could be concluded that, the most active extractions of vegetative parts and flowers were petroleum ether and chloroform extracts, respectively. The compounds of these two fractions were isolated, purified and identified. Two compounds were isolated from the vegetative parts namely, 7, 3', 4' trimethoxy quercetin and hahnfett and one compound from the flowers (stewertiisin B). The antimicrobial activity of the three isolated compounds were investigated and found that, 7, 3', 4' trimethoxy quercetin and stewertiisin B posses activity against Klebsiella pneumonia and Staphylococci aureus, while hahnfett was active against Escherichia coli, Klebsiella pneumonia and Staphylococci aureus. It was found that, the three compounds were inactive against Proteus spp. It is recommended to further study the mechanism of action as antibacterial naturally acting agent of the isolated compounds, as well as studying the ability to produce them using tissue culture techniques to facilitate their industrialization. 


\section{REFERENCES}

Ben Amor, I.L., J. Boubaker, M. Ben Sgaier, I. Skandrani, W. Bhouri, A. Neffati, S. Kilani, I. Bouhlel, K. Ghedira and L. Chekir-Ghedira (2009). Phytochemistry and biological activities of Phlomis species. Journal of Ethnopharmacology, 125 (2): 183-202.

Bucar, F., S. Ninov, I. Ionkova, T. Kartnig, M. Schubert-Zsilavecz, I. Asenov and B. Konuklugil (1998). Flavonoids from Phlomis nissolii. Phytochemistry, 48 (3): $573-575$.

Bülent, C., C. Songul and C. Ramazan (2011). The investigation of antimicrobial activity of thyme and oregano essential oils. Turk. J. Agric., 35: 145-154.

Burt, S. (2004). Essential oils: Their antibacterial properties and potential applications in foods - A review. International Journal of Food Microbiology, 94: 223- 253.

El-Negoumy, S.I., M.F. Abdalla and N.A.M. Saleh (1986). Flavonoids of Phlomis aurea and P. floccosa. Phytochemistry, 25 (3): 772-774.

Hanene, M., R.B. Slama, D. Mili, S. Zouari, A. Bakhrouf and E. Ammar (2013). Essential oil of Thymus vulgaris L. and Rosmarinus officinalis L.: Gas chromatography-mass spectrometry analysis, cytotoxicity and antioxidant properties and antibacterial activities against foodborne pathogens. Natural Science, 5 (6): 729-739.

Jabeen, B., N. Riaz, M. Saleem, M.A. Naveed, M. Ashraf, U. Alam, H.M. Rafiq, R.B. Tareen and A. Jabbar (2013). Isolation of natural compounds from Phlomis stewartii showing $\alpha$ - glucosidase inhibitory activity. Phytochemistry, 96: 443-448.

Kalemba, D. and A. Kunicka (2003). Antibacterial and antifungal properties of essential oils. Current Medicinal Chemistry, 10 (10): 813-829.

Kamel, M.S., K.M. Mohamed, H.A. Hassanean, K. Ohtani, R. Kasai and K. Yamasaki (2000). Iridoid and megastigmane glycosides from Phlomis aurea. Phytochem., 55: 353-357.

Kateryna, K. and R. Mahendra (2012). Antibacterial activity of Thymus vulgaris essential oil alone and in combination with other essential oils. Bioscience, 4 (2): 50-56.

Kirmizibekmez, H., P. Montoro, S. Piacente, C. Pizza, A. Doenmez and I. Calis (2005). Identification by HPLCPAD-MS and quantification by HPLC-PAD of phenylethanoid glycosides of five Phlomis species. Phytochem. Anal., 16 (1): 1-6.

Egyptian J. Desert Res., 66, No. 1, 69-78 (2016) 
Sarkhail, P., E.H.R. Monsef, G. Amin, M.H.S. Surmaghi and A. Shafiee (2006). Phytochemical study of Phlomis olivieri Benth. and Phlomis persica Boiss. DARU., 14: 115-121.

Vivek, S., S. Nisha, P. Vijaylata, M.A. Reyaz, S. Bikramand and G.C. Raghbir (2010). GC-MS analysis and antimicrobial activity of essential oil of Mentha piperita L. from Kullu-a North Indian region of higher altitude Himalayas. Int. J. Drug Dev. Res., 2 (4): 40-46.

Received: 21/8/2016

Accepted: 28/10/2016 
الأنشطة المضادة للبكتريا لبعض المكونات الفعالة لنبات ضرس الثايب

رحاب أحمد لطفى وهبة إبراهيم عبد المعطي"

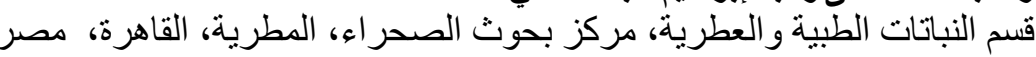

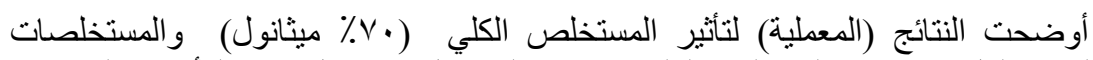

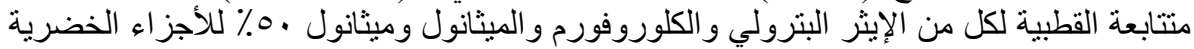

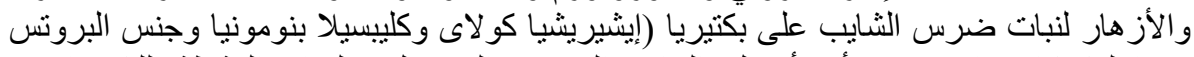

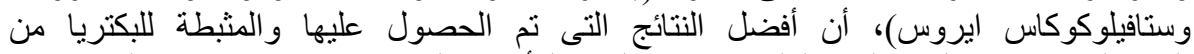

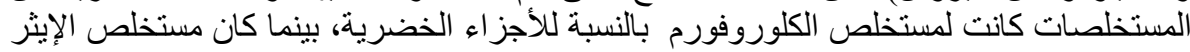

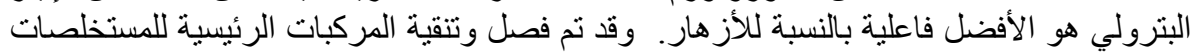

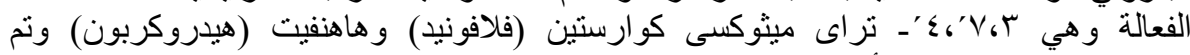

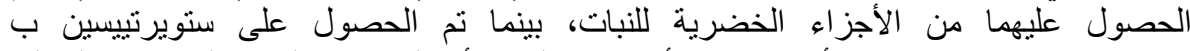

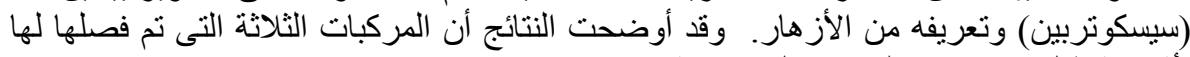

تأثير مثبط لنمو سلالات البكتيريا المستخدمة.

Egyptian J. Desert Res., 66, No. 1, 69-78 (2016) 